Boston University School of Law

Scholarly Commons at Boston University School of Law

Faculty Scholarship

$5-2020$

Tear Gas + Water Hoses + Dispersal Orders: The Fourth

Amendment Endorses Brutality in Protest Policing

Karen Pita Loor

Follow this and additional works at: https://scholarship.law.bu.edu/faculty_scholarship

Part of the Fourth Amendment Commons, and the Law Enforcement and Corrections Commons 


\title{
TEAR GAS + WATER HOSES + DISPERSAL ORDERS: THE FOURTH AMENDMENT ENDORSES BRUTALITY IN PROTEST POLICING
}

\author{
KAREN J. Pita LOOR*
}

\begin{abstract}
Thirty years ago, in Graham v. Connor, the Supreme Court determined that excessive-force claims against police should proceed via the Fourth Amendment, which theoretically protects an individual against unreasonable siezures. However, the Court showed extreme deference to law enforcement's use of force by using a permissive reasonableness analysis that bestows on police great leeway to make quick split-second decisions in tense and rapidly evolving circumstances. The result is a test that, from its inception, has been too forgiving of police violence and misconduct. This lax reasonableness standard, along with qualified immunity principles, has shielded police from $\$ 1983$ civil rights litigation in excessive-force cases. However, the obstacles to relief are worse when the victim is not an individual in a regular street encounter but rather an activist during a protest - particularly an activist of color.

This Essay explores this phenomenon through the lens of the Dundon v. Kirchmeier litigation that stemmed from the 2016 police assault on indigenous protestors opposing the Dakota Access Pipeline. The encounter left 200 activists injured after law enforcement blasted them overnight with tear gas, special impact munitions, and fire hoses to remove them from the area. In refusing to enjoin the police's use of these weapons against water protectors, the judge questioned whether the Fourth Amendment even protected activists since police sought to disperse them, instead of arrest them. The judge then reasoned that even if the Fourth Amendment applied, the police use of force was reasonable considering the volatility of the crowd despite information that the plaintiffs themselves were peaceful - thus attributing the conduct of the entire group to the plaintiffs and erroneously amplifying the threat to law enforcement. Both lines of reasoning threaten the safety of protestors. The first removes from Fourth Amendment protection the emblematic protest scenario where police use
\end{abstract}

* Associate Clinical Professor of Law, Boston University School of Law. I am grateful to Khiara M. Bridges, James E. Fleming, and Osagie K. Obasogie for their guidance, as well as to all panelists in the Boston University Law Review Symposium, Beyond Bad Apples: Exploring the Legal Determinants of Police Violence (2019). This Essay greatly benefited from the feedback of Naomi Mann and Sarah Sherman-Stokes. Thank you to Deanna Tamborelli for invaluable research assistance. I am indebted to Penélope P. Zambrana and Joseph E. Staska for their patience and support. 
force to disperse protestors. The second turns the Constitution on its head, foregoing traditional Fourth Amendment analysis, which inquires whether the government intrusion is reasonable in light of the individual's actions, not the actions of the whole group in proximity to the individual. This is most dangerous to activists of color who are most likely to be perceived as threatening by police and to be the subject of their ire. 


\section{CONTENTS}

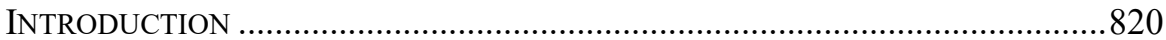

I. GRAHAM AND LIMITS OF FOURTH AMENDMENT ANALYSIS ON POLICE-EXCESSIVE-FORCE CASES.

II. ACTIVISTS OF COLOR ARE THE MORE LiKELY ViCTIMS OF VIOLENCE IN PROTEST POLICING

III. PROTEST CASES AS A SOURCE OF INQUIRY FOR CRITICAL

RACE THEORISTS.

A. Due to Troubling Developments in Court Doctrine, the Fourth Amendment Arguably Does Not Apply in the Emblematic Protest Scenario Where Police Use

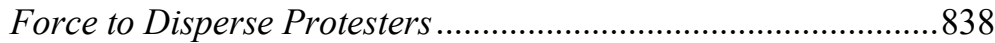

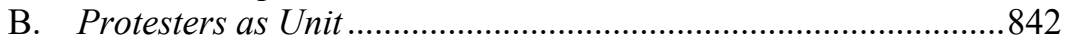

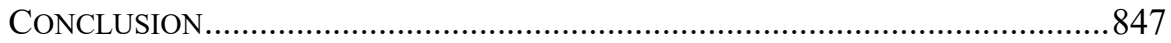




\section{INTRODUCTION}

On November 20, 2016, members of the Oceti Šakowin tribe and others stood on top of the Backwater Bridge together in prayer and protest in opposition to the construction of a 1172-mile-long pipeline that would transfer fuel from North Dakota to Illinois. ${ }^{1}$ The water protectors ${ }^{2}$ opposed the pipeline for both spiritual and environmental reasons. ${ }^{3}$ They were unarmed. ${ }^{4}$ Still, police descended upon the activists like a military unit-aboard armored vehicles and fully loaded with special impact munitions, ${ }^{5}$ tear gas, water cannons, and fire hoses - to clear them from the area. ${ }^{6}$ In the evening and early morning, law enforcement blasted activists with weapons and sprayed them with water for several hours in freezing temperatures. ${ }^{7}$ At the conclusion of this assault, more than two hundred water protectors were injured, ${ }^{8}$ including twenty-six who required hospitalization. ${ }^{9}$ Injuries ranged from loss of vision and broken bones to hypothermia. ${ }^{10}$

This aggression was not aberrational or unique to indigenous protests of the Dakota Access Pipeline ("DAPL"). Just in the last five years, a sampling of protests by activists of color outraged by police killings of black men in Baltimore, Baton Rouge, and Ferguson prompted similarly violent, excessive,

${ }^{1}$ First Amended Civil Rights Class Action Complaint for Damages \& Injunctive \& Declaratory Relief at 2, 7-8, Dundon v. Kirchmeier, No. 1:16-cv-00406 (D.N.D. Feb. 27, 2018) [hereinafter Dundon Amended Complaint].

2 Activists termed themselves "water protectors" instead of protesters. See Iyuskin American Horse, 'We Are Protectors, Not Protesters': Why I'm Fighting the North Dakota Pipeline, The Guardian (Aug. 18, 2016, 11:06 AM), https://www.theguardian.com/usnews/2016/aug/18/north-dakota-pipeline-activists-bakken-oil-fields [https://perma.cc /5UM3-NZNV]; see also Dundon Amended Complaint, supra note 1, at 9.

${ }^{3}$ Lauren Donovan, Sioux Spirit Camp to Protest Dakota Access Pipeline, Bismarck TriB. (Mar. 29, 2016), https://bismarcktribune.com/news/state-and-regional/sioux-spirit-camp-toprotest-dakota-access-pipeline/article_4773fba1-f3bb-599d-96a4-7d1ddf30690e.html.

${ }^{4}$ Dundon Amended Complaint, supra note 1, at 3.

5 See Dave Young, Definition and Explanation of Less-Lethal, PoliceOne.com (Nov. 28, 2004), https://www.policeone.com/corrections-training/articles/94021-Definition-andexplanation-of-less-lethal/ [https://perma.cc/7W58-EPBE].

${ }^{6}$ Dundon Amended Complaint, supra note 1, at 1-2, 14.

${ }^{7}$ Id. at 3, 14-15, 38.

${ }^{8} I d$. at 3. One police officer also reported a minor injury. Id. at 15.

9 Julia Carrie Wong, Dakota Access Pipeline: 300 Protesters Injured After Police Use Water Cannons, THE GuARDiAn (Nov. 21, 2016, 5:07 PM), https://www.theguardian.com/usnews/2016/nov/21/dakota-access-pipeline-water-cannon-police-standing-rock-protest [https://perma.cc/G5FE-23HD].

${ }^{10}$ Dundon Amended Complaint, supra note 1, at 16, 22-24, 26-28, 30 (alleging plaintiffs suffered head wounds, concussions, lasting pain, difficulty walking, chemical burns, and broken bones). 
and militaristic law enforcement responses. ${ }^{11}$ Protests by whites are treated differently. For example, one may recall the restrained law enforcement response to white, antigovernment militiamen who seized federal lands and property in Nevada and Oregon. ${ }^{12}$ This disparate treatment is unfortunately in line with abusive and brutal policing in minority communities and with law enforcement officers' predisposition to view people of color - and consequently activists of color - as threatening or dangerous. ${ }^{13}$ It is also nothing new. The American "system of free speech" has historically treated activists of color with hostility. "In the $1960 \mathrm{~s}$, minorities sat in, were arrested and convicted[,] ... demonstrated, sang 'We Shall Overcome,' and were arrested and convicted." 15 In his last speech before his assassination, Dr. Martin Luther

${ }^{11}$ See Office of Cmty. Oriented Policing Servis., U.S. DOJ, After-Action Assessment of the Police Response to the August 2014 Demonstrations in Ferguson, Missouri, at xvi, 53-60 (2015) [hereinafter DOJ FERGUSON REPORT], https://www.police foundation.org/wp-content/uploads/2018/08/After-Action-Assessment-of-the-Police-

Response-to-the-August-2014-Demonstrations-in-Ferguson-Missouri.pdf [https://perma.cc /DLV7-WZPF] (assessing police response in Ferguson and identifying themes that "permeated all aspects of the police response"); Conor Friedersdorf, Police Face Civilian Protesters-Dressed for Military Combat, The ATLANTIC (Aug. 12, 2014), https://www.the atlantic.com/national/archive/2014/08/ferguson-police-face-civil-rights-protest-dressed-formilitary-combat/375962/ (describing photograph of armed police in camouflage uniforms in Ferguson "squaring off against a nonviolent protestor in a t-shirt and jeans with both of his hands raised over his head"); Maya Lau, Helping or Hurting? Police Deploy Military-Style Gear at Alton Sterling Protests in Baton Rouge, The Advocate (July 11, 2016, 8:50 PM), https://www.theadvocate.com/baton_rouge/news/article_5b4c6f61-632a-5824-b271-

38b2e2eda7ae.html [https://perma.cc/B7UJ-6MM8]; Collier Meyerson, Protesters Against Police Violence Risk the Very Thing They're Fighting, THE NATION (Dec. 1, 2017), https://www.thenation.com/article/protesters-against-police-violence-risk-the-very-thingtheyre-fighting/ (describing trauma caused by police response in Baton Rouge).

12 See Ryan Lenz \& Mark Potok, S. Poverty Law Ctr., War in the West: The Bundy RANCh Standoff and the American Radical Right 5, 9-11 (Heidi Beirich ed., 2014), https://www.splcenter.org/sites/default/files/d6_legacy_files/downloads/publication/war_in_ the_west_report.pdf [https://perma.cc/7W8B-FP8N] (describing how officers withdrew without engaging in violence); Jennifer Williams, The Oregon Militia Standoff, Explained, Vox (Jan. 26, 2016, 10:30 PM), https://www.vox.com/2016/1/3/10703712/oregon-militiastandoff [https://perma.cc/7DHX-F4SB] (describing response to militia seizure of federal wildlife refuge in Oregon); see also Justin Hansford, The First Amendment Freedom of Assembly as a Racial Project, 127 YALE L.J.F. 685, 707-08 (2018).

13 See Lesley J. Wood, Crisis and Control: The Militarization of Protest Policing 41-42 (2014) ("Police and intelligence agents are much more likely to label protesters from poor or racially marginalized communities, ideologically oriented protesters, and youthful protesters [as uncooperative or threatening].”).

14 Richard Delgado \& Jean Stefancic, Understanding Words That Wound 207, 221 (2004).

15 Id. at 207. 
King Jr. recalled confronting police water hoses and dogs in Birmingham, Alabama:

And we just went on before the dogs and we would look at them; and we'd go on before the water hoses and we would look at it, and we'd just go on singing "Over my head I see freedom in the air." And then we would be thrown in the paddy wagons . ... ${ }^{16}$

The pervasive problem of violent protest policing of activists of color has the same root causes as generalized police violence in communities of color and deserves similar attention. It is a vital line of inquiry for critical race theorists. The right to express dissent unhampered by the fear of police retribution and violence, like the right to walk the streets unharmed by the government, is an element of equal membership in a democracy. It is not the right of a privileged group. However, the freedom to complain and express opposition is elusive for activists of color, and courts unfortunately reinforce this condition through their treatment of mass protests. As Dr. King noted wistfully in that same last speech,

But somewhere I read of the freedom of assembly. Somewhere I read of the freedom of speech.

Somewhere I read of the freedom of press. Somewhere I read that the greatness of America is the right to protest for right. And so just as I say, we aren't going to let dogs or water hoses turn us around .... We are going on. ${ }^{17}$

Nevertheless, minority protesters and their allies are still the more likely victims of militarized and violent protest policing. Such was the case at the Backwater Bridge in North Dakota.

The confrontation on Backwater Bridge is the subject of the Dundon $v$. Kirchmeier ${ }^{18}$ class action lawsuit. In their complaint, the plaintiffs - indigenous water protectors - alleged that police used excessive force in contravention of the Fourth and Fourteenth Amendments, chilled their First Amendment expression, and violated their equal protection rights. ${ }^{19}$ Although the matter is still pending, early in the case the district judge refused to enjoin police from using these less-than-lethal weapons against water protectors, and the Eighth Circuit affirmed. ${ }^{20}$ In ruling against the injunction on the police's use of force, the district judge began by querying how the Fourth Amendment may apply to

${ }^{16}$ Martin Luther King Jr., Martin Luther King's Final Speech: 'I've Been to the Mountaintop'-The Full Text, ABC News (Apr. 3, 2013, 3:19 PM), https://abcnews.go.com /Politics/martin-luther-kings-final-speech-ive-mountaintop-full/story?id=18872817

[https://perma.cc/4ZB4-LEVU].

${ }^{17} \mathrm{Id}$.

18 Dundon Amended Complaint, supra note 1, at 2.

19 See id. at 38-39.

${ }^{20}$ Dundon v. Kirchmeier, No. 1:16-cv-00406, 2017 WL 5894552, at *20 (D.N.D. Feb. 7, 2017), aff'd mem., 701 F. App'x 538 (8th Cir.) (per curiam). 
police action. ${ }^{21}$ This is because thirty years ago, in Graham v. Connor, ${ }^{22}$ the Supreme Court determined that excessive-force claims should proceed via the Fourth Amendment. ${ }^{23}$ This ruling has led to the evisceration of the overwhelming majority of excessive-force claims in one-on-one civilian-police encounters and to the evaluation of police brutality through a too-narrow and individualistic lens. ${ }^{24}$ The district judge's treatment of the Fourth Amendment in Dundon led him to conclude that the plaintiffs were unlikely to succeed on the merits. ${ }^{25}$

The Dundon case demonstrates how claims of excessive police force during protests are even more challenging for plaintiffs than when asserted during regular street interactions between police and civilians. Part I of this Essay describes the Graham case and the manner in which the cabining of excessiveforce analysis within the Fourth Amendment, together with qualified immunity doctrine, acts as a nearly impenetrable bar to $\S 1983$ litigation against police officers generally. Part II demonstrates that, just like police are more likely to violently target people of color in street encounters, law enforcement is more likely to confront activists of color violently. Thus, the rights and safety of people of color are particularly at risk during protests. Part III uses the district court opinion denying an injunction in Dundon to show how Graham interacts with other Fourth Amendment doctrine to make matters worse for individuals seeking relief from police-excessive-force cases in the emblematic protest scenario where force is used to disperse activists rather than to detain them.

${ }^{21} I d$. at $* 18-19$.

22490 U.S. 386 (1989).

${ }^{23} I d$. at 388 (holding that excessive-force claims are "properly analyzed under the Fourth Amendment's 'objective reasonableness' standard, rather than under a substantive due process standard").

${ }^{24}$ See, e.g., Brandon Garrett \& Seth Stoughton, A Tactical Fourth Amendment, 103 VA. L. REV. 211, 216 (2017) ("[I]11-considered statements in Graham and other decisions reinforce a 'split-second' theory of policing that sets the wrong constitutional floor."); Osagie K. Obasogie \& Zachary Newman, The Futile Fourth Amendment: Understanding Police Excessive Force Doctrine Through an Empirical Assessment of Graham v. Connor, 112 Nw. U. L. REV. 1465, 1497 (2018) ("The Fourth Amendment, as interpreted post-Graham, simply operates at the wrong level; its individualist nature cannot address a fundamentally structural problem.").

25 Dundon, 2017 WL 5894552, at *19 (finding that no reasonable juror could conclude that force used by police at Backwater Bridge was "objectively unreasonable"). Chief Judge Hovland further denied the injunction based on the plaintiffs' Fourteenth Amendment claim, stating that the police conduct did not "shock[] the conscience." Id. (quoting Wilson v. Spain, 209 F.3d 713, 716 (8th Cir. 2000)). The judge also ruled that the plaintiffs were trespassing on property closed to the public and therefore had no right to engage in First Amendment activity. Id. at *20. In their Amended Complaint, the plaintiffs later highlighted that they were situated in a location open to the public. Dundon Amended Complaint, supra note 1, at 2, 12. The judge further ruled that any equal protection claim was dependent on the outcome of the excessive-force and First Amendment claims. Dundon, 2017 WL 5894552, at*16. 


\section{GRAHAM AND LIMITS OF FOURTH AMENDMENT ANALYSIS ON POLICE-EXCESSIVE-FORCE CASES}

Over thirty years ago, the Supreme Court in Graham v. Connor considered the manner in which excessive-force claims against police should proceed. ${ }^{26}$ Before Graham, lower courts were split as to what legal standard to apply to a claim of police excessive force in interactions with civilians during investigatory stops or arrests. The majority of courts applied Fourteenth Amendment due process, requiring plaintiffs to demonstrate that the officer had subjective malicious intent, while other courts applied the Fourth Amendment and required plaintiffs to show that the officer's conduct failed to meet the "objective reasonableness" standard. ${ }^{27}$

The facts of Graham were as follows: Mr. Dethorne Graham, a black man, ${ }^{28}$ was in the midst of a diabetic crisis and was searching for orange juice when police officers observed him enter and quickly leave a convenience store, get into his friend's car, and drive away. ${ }^{29}$ With no additional information, Charlotte Police Officer M.S. Connor stopped the car and, despite explanations from both the driver and Mr. Graham that the latter was having a diabetic reaction, ordered them both to wait while he investigated what had occurred at the store. ${ }^{30} \mathrm{Mr}$. Graham then exited the car and ran around it twice. He then sat on the sidewalk and began talking to his friend, the driver. ${ }^{31}$ Additional police arrived in response to Connor's request for backup. Ignoring the driver's pleas for candy or juice for his friend, police pushed the driver aside, rolled Mr. Graham on his belly, and handcuffed his hands behind his back. ${ }^{32}$ At some point, Mr. Graham passed out. He regained consciousness after officers lifted him and placed him face down on the hood of the police car. ${ }^{33}$ Officers told Mr. Graham to "shut up" and pushed his face against the car when he asked them to look in his wallet for his diabetic card. The officers then threw Mr. Graham "headfirst into the police car" and refused to allow him to have the juice his friend brought to the car. ${ }^{34}$ Finally, the officers heard back that there was no incident at the store, drove Mr. Graham

26 Graham, 490 U.S. at 388.

27 Id. at 392-93.

${ }^{28}$ Brief for the Petitioner at 3, Graham, 490 U.S. 386 (No. 87-6571), 1988 WL 1025786, at $* 3$ [hereinafter Graham Petitioner Brief].

${ }^{29}$ Graham, 490 U.S. at 388-89.

${ }^{30}$ Id. at 389.

${ }^{31} \mathrm{Id}$.

${ }^{32} I d$. (reporting that one officer stated: "I've seen a lot of people with sugar diabetes that never acted like this. Ain't nothing wrong with the M. F. but drunk. Lock the S. B. up").

${ }^{33} I d$.

${ }^{34} I d$. 
home, and released him. ${ }^{35} \mathrm{Mr}$. Graham sustained injuries as a result of the police officers' conduct, including a permanent ringing in his ear. ${ }^{36}$

The civil rights lawsuit proceeded to trial in the District Court for the Western District of North Carolina. ${ }^{37}$ Before a jury verdict, the district judge granted the defendant's motion for a directed verdict on the issue of excessive force, applying the existing test for substantive due process, which consisted of the following factors:

(1) The need for the application for the force.

(2) The relationship between the need and the amount of the force that was used.

(3) The extent of the injury inflicted.

(4) Whether the force was applied in a good faith effort to maintain and restore discipline or maliciously and sadistically for the very purpose of causing harm. ${ }^{38}$

The judge ruled that the force was "appropriate under the circumstances," the victim was not injured, and the officer acted in good faith "to maintain or restore order in the face of a potentially explosive situation" and not "maliciously or sadistically." 39 The Fourth Circuit affirmed the trial court's decision using the same due process analysis. ${ }^{40}$

In his brief to the Supreme Court, Graham argued that a Fourteenth Amendment substantive due process analysis was inappropriate and that the Fourth Amendment should be applied to the excessive-police-force claims. ${ }^{41}$ Graham emphasized that the Fourth Amendment applied because he was clearly seized by the police officers. ${ }^{42}$ The Supreme Court agreed and reversed the trial court's decision, thereby settling the split among lower courts as to whether to apply the Fourth or Fourteenth Amendment. Reasoning that the Fourth Amendment protects against unreasonable seizures, the Court held that where "the excessive force claim arises in the context of an arrest or investigatory stop of a free citizen, it is most properly characterized as one invoking the protections of the Fourth Amendment." 43 The Court stated that "all claims that law enforcement officers have used excessive force ... in the course of an arrest, investigatory stop, or other 'seizure' of a free citizen should be analyzed under

\footnotetext{
$35 I d$.

${ }^{36} I d$. at 390 (noting that, in total, Graham claimed to have sustained broken foot, cuts on wrists, bruises on forehead, injured shoulder, and ringing in right ear).

37 Graham v. City of Charlotte, 644 F. Supp. 246, 248 (W.D.N.C. 1986), aff'd, 827 F.2d 945 (4th Cir. 1987), vacated, 490 U.S. 396 (1989).

${ }^{38}$ Id. (citing King v. Blankenship, 636 F.2d 70, 73 (4th Cir. 1980)).

${ }^{39}$ Id.

40 Graham, 490 U.S. at 391.

41 Graham Petitioner Brief, supra note 28, at 8.

${ }^{42} I d$. at 10.

43 Graham, 490 U.S. at 394, 396.
} 
the Fourth Amendment and its 'reasonableness' standard." 44 Relevant for later discussion, the Graham Court defined a seizure, pursuant to Terry v. Ohio, ${ }^{45}$ as "when government actors have, 'by means of physical force or show of authority, ... in some way restrained the liberty of a citizen." 46 Although Graham advocated for the application of the Fourth Amendment, the Court defined "reasonableness" in a manner that was problematic for future plaintiffs - including Mr. Graham, who lost in his post-remand trial. ${ }^{47}$ In its customary display of colorblindness, the Court failed to state Mr. Graham's race.

In Graham, the Court defined the "calculus of reasonableness" in a manner that immunizes aggressive police misconduct post-Graham and provides excessive deference to law enforcement, who the Court bemoaned are "often forced to make split-second judgments - in circumstances that are tense, uncertain, and rapidly evolving." 48 The application of this version of reasonableness to post-Graham excessive-force cases has left civilians with no recourse against violent police conduct and arguably has allowed police to get away with murder. ${ }^{49}$

There are two federal vehicles for either the government or individual plaintiffs to seek remediation for violent police misconduct. Under 18 U.S.C. $\S 242$, the federal government - via the Department of Justice ("DOJ") — can prosecute a police officer who has violated an individual's constitutional rights "on account of such person being an alien, or by reason of his color, or race." 50 Under 42 U.S.C. § 1983-the Civil Rights Act — an individual plaintiff can bring a civil lawsuit asserting that a police officer violated their constitutional rights. ${ }^{51}$ For example, $\S 1983$ was the vehicle for the lawsuit in Graham..$^{52}$ In view of Graham, courts have consistently cabined excessive-force analysis within the Fourth Amendment in both $\S 242$ cases and $\S 1983$ cases.

In $\S 242$ criminal prosecutions, despite the Graham language that the due process test requirement of malicious intent "is incompatible with a proper Fourth Amendment analysis,"53 the government must prove "evil motive"

\footnotetext{
${ }^{44} I d$. at 395.

45392 U.S. 1 (1968).

${ }^{46}$ Graham, 490 U.S. at 395 n.10 (alteration in original) (quoting Terry, 392 U.S. at 19 n.16).

47 See id. at 396; Alice Ristroph, The Constitution of Police Violence, 64 UCLA L. REV. 1182, 1207 (2017).

48 Graham, 490 U.S. at 397.

49 See Erwin Chemerinsky, Editorial, How the Supreme Court Protects Bad Cops, N.Y. Times, Aug. 27, 2014, at A23.

5018 U.S.C. $\S 242$ (2018).

5142 U.S.C. $\S 1983$.

52 Graham, 490 U.S. at 388.

${ }^{53}$ Id. at 397.
} 
beyond a reasonable doubt for a conviction. ${ }^{54}$ Specifically, the prosecutor must show that the officer knew that their conduct was a violation of the victim's constitutional rights and that the officer committed the act for that purpose..$^{55}$ Thus, scholars have asserted that Graham ultimately did nothing to dispel the intent requirement for civil rights prosecutions. ${ }^{56}$ This is evidenced in the DOJ's decision not to prosecute Police Officer Darren Wilson, having concluded it could not show that Officer Wilson acted willfully to violate Michael Brown's constitutional rights when he shot the teenager between six and eight times. ${ }^{57}$ What's more, even without this "evil motive" requirement, the DOJ would have decided not to prosecute because it concluded, citing the deferential language of Graham, that the "shots fired by Wilson were [not] objectively unreasonable." 58 Although Officer Wilson claimed that he mistakenly believed that Michael Brown had a gun when he fired, the DOJ Report clearly states that even if Officer Wilson knew that Brown was walking toward him unarmed and with his hands up, Graham's progeny establishes that the officer can shoot him and the officer's

\footnotetext{
${ }^{54}$ Screws v. United States, 325 U.S. 91, 101 (1945) ("An evil motive to accomplish that which the statute condemns becomes a constituent element of the crime.").

55 See id. (interpreting statutory requirement of "willful"); see also U.S. DOJ, REPORT Regarding the Criminal Investigation into the Shooting Death of Michael Brown 85-86 (2015) [hereinafter DOJ MiCHAEL BROWN REPORT], https://www.justice.gov/sites /default/files/opa/press-releases/attachments/2015/03/04/doj_report_on_shooting_of_ michael_brown_1.pdf [https://perma.cc/YZ83-YUSA] (concluding that in Michael Brown shooting, DOJ did not think it would have been able to prove willfulness beyond reasonable doubt); Law Enforcement Misconduct, U.S. DOJ, https://www.justice.gov/crt/lawenforcement-misconduct [https://perma.cc/YNP2-KH69] (last updated Feb. 25, 2019) (describing necessary steps for successful prosecution under statute).

56 See Jill I. Brown, Comment, Defining "Reasonable" Police Conduct: Graham v. Connor and Excessive Force During Arrest, 38 UCLA L. REV. 1257, 1260 (1991) ("When courts require proof of subjective intent or significant injury, they effectively convert the fourth amendment inquiry into a due process test, depriving civil rights plaintiffs of Graham's benefit.").

57 DOJ Michael Brown ReporT, supra note 55, at 11-12, 85-86. The DOJ investigations into the police-involved deaths of Eric Garner and Freddie Gray reached the same conclusion not to prosecute. See Bobby Allyn, NYPD Officer Will Not Face Federal Criminal Charges in Eric Garner's Death, NPR (July 16, 2019, 10:47 AM), https://www.npr.org/2019/07/16 /742186042/nypd-officer-wont-face-federal-criminal-charges-in-eric-garner-s-deathsources-s [https://perma.cc/24UU-HA2Y]; Alvin Bragg, Opinion, Eric Garner Is Proof That We Need to Reform Laws on Excessive Force, WASH. Post (July 17, 2019, 5:55 PM), https://www.washingtonpost.com/opinions/2019/07/17/eric-garner-is-proof-that-we-needreform-laws-excessive-force/; Press Release, Office of Pub. Affairs, U.S. DOJ, Federal Officials Decline Prosecution in the Death of Freddie Gray (Sept. 12, 2017), https://www.justice.gov/opa/pr/federal-officials-decline-prosecution-death-freddie-gray [https://perma.cc/5VB2-V3NU].

58 DOJ Michael Brown Report, supra note 55, at 7, 10, 85.
} 
actions must be deemed reasonable and not excessive. ${ }^{59}$ Essentially, the law will excuse an officer's use of deadly force in an interaction with a civilian as long as the individual has not already surrendered. ${ }^{60}$ This result demonstrates how inconsistent the Fourth Amendment analysis under $\S 242$ is with any manner in which individuals assess reasonableness in regular parlance.

Alternatively, $\S 1983$ of the Civil Rights Act is the vehicle for individual and class action suits for excessive police force. ${ }^{61}$ However, Graham, together with qualified immunity principles, has blunted the utility of $\S 1983$ actions to counteract excessive police force. In addition to the Court's lax "reasonableness" standard, qualified immunity allows a police officer to avoid liability unless they know that their action is unlawful before acting. The qualified immunity doctrine has developed such that police officers can avoid suit unless the plaintiff can point to a preceding case in which a police officer acted in a factually analogous manner and the court found that his conduct violated the Fourth Amendment. ${ }^{62}$ Otherwise, the lawsuit will be dismissed. This barrier from suit not only shields the police officer but also prevents the law from developing further. As a result, courts will rarely have to grapple with the question of whether a police officer's conduct was unconstitutional. This may be why representatives of decedents in police-killing cases routinely sue via wrongful death instead of $\S 1983 .{ }^{63}$ The families of Michael Brown, Eric Garner, and Freddie Gray obtained recovery via settlement of their wrongful death actions. ${ }^{64}$

${ }^{59} I d$. (finding sufficient evidence that Wilson reasonably believed that Brown posed deadly threat, and that use of deadly force was therefore not unreasonable).

${ }^{60}$ Id. at 12, 84-85 (citing Loch v. City of Litchfield, 689 F.3d 961, 966 (8th Cir. 2012) (finding officer's use of deadly force was not unreasonable even where victim's arms were above his head and he was slowly advancing toward the officer)).

6142 U.S.C. § 1983 (2018).

62 See Karen J. Pita Loor, When Protest Is the Disaster: Constitutional Implications of State and Local Emergency Power, 43 Seattle U. L. ReV. 1, 65 (2019); see also Avidan Y. Cover, Reconstructing the Right Against Excessive Force, 68 FLA. L. REV. 1773, 1789 (2016) (describing how qualified immunity "stagnat[es] constitutional development"); Diana Hassel, Excessive Reasonableness, 43 IND. L. REV. 117, 124-29 (2009) (discussing how courts merge Fourth Amendment inquiry and qualified immunity question in excessive-force cases); Tahir Duckett, Note, Unreasonably Immune: Rethinking Qualified Immunity in Fourth Amendment Excessive Force Cases, 53 AM. CRIM. L. REV. 409, 411 (2016) (evaluating "intersection of the reasonableness inquiry at the center of Fourth Amendment excessive-force claims, and the reasonable person standard of the qualified immunity defense").

63 See Steven H. Steinglass, Wrongful Death Actions and Section 1983, 60 InD. L.J. 559, 561 (1985).

${ }^{64}$ David Carson, Michael Brown's Family Received \$1.5 Million Settlement with Ferguson, NBC News (June 23, 2017, 9:58 AM), https://www.nbcnews.com/storyline /michael-brown-shooting/michael-brown-s-family-received-1-5-million-settlementferguson-n775936 [https://perma.cc/HT26-HLPS]; Julia Marsh, City Approves \$4M Payment to Eric Garner's Family, N.Y. Post (Aug. 2, 2017, 7:28 PM), https://nypost.com/2017/08/02 
Despite the preceding discussion's focus on tragic police killings of African Americans, it is vital to note that black men are not the only people of color who are the persistent victims of police violence. Latinx people likewise die at the hands of police at an alarming rate, ${ }^{65}$ and law enforcement kill indigenous peoples at a higher rate than any other group. ${ }^{66}$ Furthermore, while the most serious cases of police brutality lead to certain death for some civilians, for others - particularly people of color - violent police interactions can cause a dignitary "death by a thousand cuts." Victims of these violent police encounters likewise find no solace in $\S 1983$ actions and have no cause of action for wrongful death. Scholars have indicted Graham on various fronts: how its "split second" language focuses courts on the exact moment of violence and ignores how police could have been trained to de-escalate instead of escalate violence, ${ }^{67}$ how it interacts with qualified immunity to shield violent and dangerous police misconduct from court oversight, ${ }^{68}$ and how it facilitates courts ignoring and overlooking the race of victims and perpetrators of police violence. ${ }^{69}$

/city-approves-4m-payment-to-eric-garners-family/ [https://perma.cc/48NY-JG7C]; Yvonne Wenger \& Mark Puente, Baltimore to Pay Freddie Gray's Family \$6.4 Million to Settle Civil Claims, BALT. Sun (Sept. 8, 2015, 10:01 PM), https://www.baltimoresun.com/news/crime/bsmd-ci-boe-20150908-story.html.

65 Kenya Downs, Why Aren't More People Talking About Latinos Killed by Police?, PBS NEwSHOUR (July 14, 2016, 1:21 PM), https://www.pbs.org/newshour/nation/black-menwerent-unarmed-people-killed-police-last-week [https://perma.cc/M22F-TTJ4] (noting that Latinos made up $16 \%$ of police killings in 2016).

${ }^{66}$ Stephanie Woodard, The Police Killings No One Is Talking About, In THESE TIMES (Oct. 17, 2016), https://inthesetimes.com/features/native_american_police_killings_native_lives_ matter.html [https://perma.cc/SC8X-EYNA].

${ }^{67}$ See, e.g., Cover, supra note 62, at 1823 (arguing that generic due process right against excessive force could "help guard against pardoning biases... that may infect police behavior as products of 'split-second judgments"'); Garrett \& Stoughton, supra note 24, at 223-24 (arguing that Garner reasonableness test fails to address "totality of the circumstances" because it does not take into account officer preparation, training, or tactics prior to use of force).

68 See, e.g., Cover, supra note 62, at 1784-87; Hassel, supra note 62, at 124-29; Duckett, supra note 62, at 424-25.

69 See, e.g., Devon W. Carbado, Blue-on-Black Violence: A Provisional Model of Some of the Causes, 104 GEo. L.J. 1479, 1486, 1489 n.41, 1500 (2016) (describing racialized "broken windows" policing and pretextual stops that go unchecked by courts); Christian M. Halliburton, Race, Brain Science, and Critical Decision-Making in the Context of Constitutional Criminal Procedure, 47 Gonz. L. REv. 319, 332-35 (2011) (addressing "negative association" with people of color that lead police to assume "heightened propensity for violence and criminality in black men" that courts do not consider in reasonableness calculation); Obasogie \& Newman, supra note 24, at 1470 ("[T] he Fourth Amendment is an area of constitutional law that is structurally unsuited to address racialized group harm - an evaluation that is necessary for understanding the nature of police violence today."). 


\section{Activists of COlOR ARE THE More LiKely Victims OF VIOLENCE IN PROTEST POLICING}

Graham, as previously discussed, excuses police violence through a permissive reasonableness test. As will be discussed in Part III, Graham coalesces with other Fourth Amendment doctrine to make matters worse for victims of violent and militaristic protest policing. This is of particular import to activists of color whose protest activities are more likely to be targets of excessive police attention and force. It aggregates with the high policing and surveillance in communities of color to create or aggravate racialized police violence. ${ }^{70}$

Legal scholars have given well-deserved attention to the unequal treatment and targeting of people of color during regular policing. ${ }^{71}$ The manner in which police engage aggressively with civilians of color as they walk the streets or drive in their vehicles has been closely examined. ${ }^{72}$ How law enforcement engages with protesters of color deserves similar attention and study in the legal academy and among critical race scholars. Like in regular street encounters between police and individuals of color, the racial identity of protesters affects the police response.

Certain social scientists who have examined this problem naturally have extrapolated from existing research demonstrating that police are more likely to believe that people of color carry guns ${ }^{73}$ and behave violently or criminally. ${ }^{74} \mathrm{In}$

70 See Zach Newman, Note, "Hands up, Don't Shoot": Policing, Fatal Force, and Equal Protection in the Age of Colorblindness, 43 Hastings Const. L.Q. 117, 151-53 (2015).

${ }^{71}$ See Jerome H. Skolnick, Justice Without Trial: Law Enforcement in a DEMOCRATIC SOCIETY 45-48 (1966) (discussing how implicit racial biases can lead to police shorthand that signals potential danger based solely on race); I. Bennett Capers, Policing, Race, and Place, 44 HARV. C.R.-C.L. L. REV. 43, 43-48 (2009) (discussing policing and race as they relate to institutional housing segregation); Elizabeth E. Joh, Discretionless Policing: Technology and the Fourth Amendment, 95 CALIF. L. REV. 199, 208 (2007) (describing difficulties that arise due to police assumption that "racial minorities are more likely to be engaged in criminal behavior").

72 Bennett Capers, supra note 71, at 60-62; see also The SEntencing Project, RePORT of the Sentencing Project to the United Nations Special Rapporteur on Contemporary Forms of Racism, Racial Discrimination, Xenophobia, and Related Intolerance 3-5 (2018), https:/www.sentencingproject.org/publications/un-report-on-racial-disparities/ [https://perma.cc/9HRL-RMEC]; Carbado, supra note 69, at 1486, 1489, 1500.

73 Anthony G. Greenwald, Mark A. Oakes \& Hunter G. Hoffman, Targets of Discrimination: Effects of Race on Responses of Weapons Holders, J. EXPERIMENTAL SOC. PSYCHOL., Oct. 2003, at 399, 399-405 (analyzing "signal detection theory" as method of evaluating racial biases in weapons holders).

74 See generally Elijah Anderson, Streetwise: Race, Class, And Change in AN Urban Community (1990); see also Jon Hurwitz \& Mark Peffley, Public Perceptions of Race and Crime: The Role of Racial Stereotypes, 41 AM. J. Pol. ScI. 375, 380 (1997) (“[O]ne of the most popular negative beliefs expressed about 'most' blacks is that they are 'violent and aggressive.'”). 
other words, police view people of color as more threatening in day-to-day interactions. This research translates to how police perceive protesters of color versus white protesters. Just like they do during routine policing, law enforcement view people of color as more threatening and dangerous than whites during protests. ${ }^{75}$ This translates to more vigilant and aggressive policing of nonwhite protesters.

A study that examined over fifteen thousand American protests during a thirty-year period found that during many of those years there was a "protesting while black" effect - although admittedly the effect was not constant during the entire period.$^{76}$ It is important to note that study did not take into account protests in the last three decades. Still, the study found that African American protests are consistently more likely to draw police presence and vigilance than are white protests. ${ }^{77}$ This is unsurprising considering that protesters of color are viewed by police as threatening. Once police are present - in some of the years studied although not all- police are then more likely to make arrests and use force and violence against African American activists. ${ }^{78}$ This "protesting while black" effect was most salient in the years leading to the enactment of civil rights legislation. ${ }^{79} \mathrm{I}$ will engage in some speculation and hypothesize that police-as state actors - engaged abusively with protesters of color prior to this legislation because they perceived true challenges to the status quo that they were trained to summarily quash. After all, police are trained to protect the existing hierarchical boundaries within our society. ${ }^{80}$ To the degree that police again perceive protests by activists of color as truly threatening current hierarchies and the status quo, they may again react increasingly aggressively and violently to these protests.

The increasing use of militarized strategies and easy access to military tools and weapons multiplies the expanse and violence of police force. While militarized strategies are not always used, they are most likely to be used when law enforcement perceive protesters as dangerous. ${ }^{81}$ Militarization thus intersects with protesters' racial identity. Police's use of military vehicles, water

75 See WooD, supra note 13, at 41-42 (describing increase of SWAT teams throughout United States, particularly at protests); see also Christian Davenport, Sarah A. Soule \& David A. Armstrong II, Protesting While Black? The Differential Policing of American Activism, 1960 to 1990, 76 AM. Soc. REv. 152, 168-69 (2011) (finding that predominantly African American protests had higher likelihood of police presence and police action).

76 Davenport, Soule \& Armstrong, supra note 75, at 169 (analogizing to "driving while black" phenomenon).

${ }^{77} I d$. (theorizing that systematic racism causes state authorities to treat African American protesters more aggressively so as to maintain status quo).

${ }^{78} I d$. at $166-68$.

${ }^{79} \mathrm{Id}$. at 168 .

80 See Cathy Lisa Schneider, Police Power and Race Riots: Urban UnRest in Paris AND NEW YORK 255 (2014).

${ }^{81}$ WoOD, supra note 13 , at 41 (stating that specialized units used for predominantly black protests were also used for armed standoffs or the "War on Drugs"). 
cannons, fire hoses, and special impact munitions against indigenous water protectors in the Dundon lawsuit evidences a militarized police response. ${ }^{82}$ In a prior article, I examined the police response to the pipeline protests and Ferguson protests and accounted for how, particularly in Ferguson, military police response was swift and unparalleled. ${ }^{83}$ People in Ferguson described feeling that police were invading the neighborhood. ${ }^{84}$ Further, the eventual discovery of communications between National Guard troops labeling Ferguson protesters a hate group ${ }^{85}$ demonstrates that the classification of minority activists as dangerous extended beyond the state police and local police. In contrast, the police response to a white nationalist protest in Charlottesville over the removal of a Confederate monument did not involve military vehicles, weapons, or tactics. ${ }^{86}$ Observers criticized law enforcement for failing to police the protests. ${ }^{87}$ If police did not view the "Unite the Right" protesters as dangerous, they were wrong. A white nationalist ran his car into a crowd, killing one counterprotester and injuring several more. ${ }^{88}$ Another counterprotester was brutally beaten with a metal pole and then arrested by police. ${ }^{89}$

However, law enforcement's fear of protesters of color is reinforced by the federal government's unwarranted historical and current preoccupation with racial justice movements. Hearkening back to the 1950s and '60s, the FBI's targeting of African American activists is well documented in the agency's own records. Stolen and subsequently leaked FBI headquarter documents revealed the persistent infiltration, surveillance, and harassment of groups termed "Black Extremists" from 1956 to $1971 .{ }^{90}$ According to the FBI operation

\footnotetext{
82 Dundon Amended Complaint, supra note 1, at 1-2.

${ }^{83}$ Pita Loor, supra note 62, at 26-29 (detailing use of SWAT teams, armored vehicles, and
} military tactics in response to protests).

${ }^{84}$ Id. at 27.

${ }^{85}$ Barbara Starr \& Wesley Bruer, Missouri National Guard's Term for Ferguson Protesters: 'Enemy Forces,' CNN (Apr. 17, 2015, 6:36 PM), https://www.cnn.com/2015/04 /17/politics/missouri-national-guard-ferguson-protesters/index.html [https://perma.cc/94H5AW7A].

${ }^{86}$ Hansford, supra note 12, at 707-08.

87 Joe Heim et al., Charlottesville Protest Takes a Deadly Turn, WAsh. Post, Aug. 13, 2017, at A14; see also Hunton \& Williams, FinAl RePORT: IndEPENDENT REVIEW OF THE 2017 Protest Events in Charlottesville, Virginia 126-27 (2017), https://www.hunton ak.com/images/content/3/4/v2/34613/final-report-ada-compliant-ready.pdf [https://perma.cc 15V7C-ZQRQ].

${ }^{88}$ Hansford, supra note 12, at 707-08; Heim et al., supra note 87, at A14.

${ }^{89}$ Hansford, supra note 12, at 707-08; see also Loulla-Mae Eleftheriou-Smith, Charlottesville: Black Protester Deandre Harris 'Beaten with Metal Poles' by White Supremacists, THE INDEPENDENT (Aug. 15, 2017, 4:48 PM), http://www.independent.co.uk /news/world/americas/charlottesville-deandre-harris-black-protester-white-supremacistsbeat-metal-poles-neo-nazis-a7894916.html.

90 See FBI Records: The Vault, COINTELPRO: Black Extremist, FBI, https://vault.fbi.gov/cointel-pro/cointel-pro-black-extremists [https://perma.cc/WTM9- 
COINTELPRO, black extremists included Martin Luther King Jr. and supporters as well as leaders of the Black Panther Party. ${ }^{91}$ The now-unclassified documents reveal multiple and serious FBI abuses, including that its agents attempted to convince King to commit suicide by threatening to reveal evidence of extramarital affairs gathered through illegal surveillance, and that they infiltrated the Black Panther Party and used information learned to conduct a raid of its leader Fred Hampton's home, which resulted in his shooting and death. ${ }^{92}$ COINTELPRO provided a clear and scary picture of a federal law enforcement agency intent on watching and targeting movements seeking racial justice and using the rhetoric of radicalization to justify its efforts. ${ }^{93}$ After COINTELPRO was exposed, the FBI terminated the operation in $1971 .{ }^{94}$

FBI focus on the activities of activists of color did not end with COINTELPRO; the FBI's monitoring of movements by people of color is alive and well today. Data shows that from 2010 to 2019, the FBI has persistently surveilled racial justice activists. ${ }^{95}$ A leaked 2017 FBI intelligence report constructs, or perhaps revives, so-called "black extremists" as a terrorism threat — now termed "Black Identity Extremist." 96 The report states that these

YJ3R] (last visited Mar. 31, 2020) [hereinafter FBI Records: The Vault]; see also Allan M. Jallon, A Break-In to End All Break-Ins, L.A. TIMES, Mar. 8, 2006, at B13 (describing breakin of FBI office revealing documents detailing surveillance of black activist groups).

91 See Betty Medsger, The Burglary 342-48 (2014); Jallon, supra note 90, at B13; FBI Records: The Vault, supra note 90.

92 Jallon, supra note 90, at B13 (describing illegal tape created and sent by FBI to King urging him to commit suicide); see also MEDSGER, supra note 91, at 342-48 (stating that FBI claimed credit for murdering Hampton in leaked internal documents); Ursula Wolfe-Rocca, COINTELPRO: Teaching the FBI's War on the Black Freedom Movement, RETHINKING ScHOOLS, https://www.rethinkingschools.org/articles/cointelpro-teaching-the-fbi-s-war-onthe-black-freedom-movement [https://perma.cc/MJ9J-UGVD] (last visited Mar. 31, 2020) (discussing FBI's involvement in death of Black Panther Leader Fred Hampton).

93 Bryan Schatz, A Former FBI Whistleblower Explains Why the Federal Government Is Failing on Domestic Terrorism - and How to Fix It, Mother JONES (Aug. 7, 2019), https://www.motherjones.com/politics/2019/08/a-former-fbi-whistleblower-explains-whythe-federal-government-is-failing-on-domestic-terrorism-and-how-to-fix-it/

[https://perma.cc/K7Q7-Q9X3] (interviewing former FBI agent on his duties to infiltrate groups deemed to be dangerous by FBI).

${ }^{94}$ Jallon, supra note 90, at B13 (discussing leak of FBI documents as end of COINTELPRO).

95 Chip Gibbons, Defending Rights \& Dissents, Still Spying on Dissent: The Enduring Problem of FBI First AMENDMEnt ABuSE 6-8 (2019), https://rightsand dissent.org/fbi-spying/ [https://perma.cc/BU8Z-6WE7] (detailing FBI's monitoring activity of civil rights groups, such as By Any Means Necessary (“BAMN”)).

96 Counterterrorism Div., FBI, (U//FOUO) Black Identity Extremists Likely Motivated to TARget LAW Enforcement OfFicers 2-4 (2017) [hereinafter FBI COUNTERTERRORISM REPORT], https://privacysos.org/wp-content/uploads/2017/10/FBIBlackIdentityExtremists.pdf [https://perma.cc/678E-G8EC] (reporting incidents of violence against police officers as reason to watch "Black Identity Extremists" more closely); see also 
Black Identity Extremists are a threat to law enforcement because their mission is to avenge the deaths of victims of police violence by killing officers. ${ }^{97}$ The FBI's conclusion that this brand of terrorists exists is unfounded, dangerous, and paranoid, with former federal agents asserting that the label simply stands for "black people who scare [the FBI]"98 and that the classification simply allows government surveillance of "basically anyone who is black and politically active." $" 99$ It conflates groups that protest racial injustice in various forms and that predominantly have African Americans as members into one single classification with a frightening goal. The FBI report lists six unconnected instances of planned or executed civilian violence against police from 2014 to 2016 as proof of a manufactured sinister goal of various predominantly African American groups. ${ }^{100}$ This is despite the fact that these assailants are best described as lone actors. ${ }^{101}$ In a hearing before Congress in July 2019, the FBI Director asserted that the agency was no longer investigating Black Identity Extremists. ${ }^{102}$ However, additional documents that were leaked later suggest that while the label may have changed, the investigative protocol remained and included the Iron Fist Program with the goal of "proactively address[ing] this priority domestic terrorism target by focusing FBI operations via enhanced

Khaled A. Beydoun \& Justin Hansford, Opinion, The F.B.I.'s Dangerous Crackdown on 'Black Identity Extremists,' N.Y. TIMES (Nov. 15, 2017), https://www.nytimes.com /2017/11/15/opinion/black-identity-extremism-fbi-trump.html (analyzing history of COINTELPRO in connection with FBI decision to create label of "Black Identity Extremists"); Miriam Zoila Pérez, What Does the FBI's New 'Black Identity Extremist' Label Really Mean to Black Organizing, COLORLINES (Oct. 25, 2017, 12:26 PM), https://www.colorlines.com/articles/what-does-fbis-new-black-identity-extremist-labelreally-mean-black-organizing [https://perma.cc/9ALL-C72L] (comparing FBI's "Black Identity Extremist" label to COINTELPRO operations in 1960s).

${ }^{97}$ FBI COUNTERTERRORISM REPORT, supra note 96, at 2 ("The FBI assesses it is very likely Black Identity Extremist (BIE) perceptions of police brutality against African Americans spurred an increase in premeditated, retaliatory lethal violence against law enforcement and will very likely serve as justification for such violence." (footnotes omitted)).

98 Beydoun \& Hansford, supra note 96.

99 Kate Irby, Protesters Are Increasingly Being Labeled Domestic Terrorist Threats, Experts Worry, IMPACT2020 (Oct 27, 2017, 5:53 PM), https://www.mcclatchydc.com/news /nation-world/national/article181358311.html [https://perma.cc/R66Y-KP5W].

100 FBI COUNTERTERRORISM REPORT, supra note 96, at 4-6; see also GIBBONS, supra note 95, at 7-11 (detailing FBI's sometimes violent responses to those labeled BIEs).

101 See FBI COUNTERTERrorism Report, supra note 96, at 4-6 (finding no connection between attackers and any racial justice groups); Beydoun \& Hansford, supra note 96 ("[The FBI Report] links incidents of violence by a handful of individual citizens . . to 'B.I.E. ideology ....'”').

102 Byron Tau, FBI Abandons Use of Term 'Black Identity Extremism,' WALL STREET J. (July 23, 2019, 10:33 PM), https://www.wsj.com/articles/fbi-abandons-use-of-terms-blackidentity-extremism-11563921355 ("We only investigate violence. We don't investigate extremism. We don't investigate ideology."). 
intelligence collection efforts." ${ }^{103}$ The facts should lead the FBI to concentrate its intelligence efforts elsewhere. The data show that when police need protection, it is from white extremists - not activists of color. Between 2001 and 2017, of the forty-five police officers tragically killed by domestic extremists, thirty-four were killed by right-wing white extremists. ${ }^{104}$ A 2009 Department of Homeland Security ("DHS") report noted the dangerous rise of this trend and warned of right-wing extremism. ${ }^{105}$ While this report was harshly criticized by conservative politicians and subsequently disavowed by then-DHS Secretary Janet Napolitano, its predictions have come to fruition in the form of multiple deadly attacks not only on police but also on civilians by white nationalists and so-called "sovereign citizens" who oppose any government authority. ${ }^{106}$

African Americans are not the only minority targets of federal law enforcement surveillance. In 2018, the ACLU obtained government documents suggesting that police were being trained with counterterrorism strategies to police indigenous protests of the Keystone pipeline. ${ }^{107}$ The same documents link

103 Patrick G. Eddington, Constitution Day 2019: The Hidden Domestic Surveillance Crisis, CATO INST. (Sept. 17, 2019), https://www.cato.org/publications/commentary /constitution-day-2019-hidden-domestic-surveillance-crisis [https://perma.cc/6UJE-3TFV]; Ken Klippenstein, FBI's Document: Iron Fist Focuses on 'Black Identity Extremist' Movement, PoPUlARRESISTANCE.ORG (Aug. 24, 2019), https://popularresistance.org/fbisdocument-iron-fist-focuses-on-black-identity-extremist-movement/ [https://perma.cc/3CLYNQA8]; see also Letter from MediaJustice to Elijah Cummings, Chairman, U.S. House Oversight \& Reform Comm., Jerry Nadler, Chairman, U.S. House Judiciary Comm., \& Bennie G. Thompson, Chairman, U.S. House Homeland Sec. Comm. (Sept 17, 2019), https://mediajustice.org/wp-content/uploads/2019/09/ProtectBlackDissent-Response-Letter1.pdf [https://perma.cc/WM9V-RP5Y] (citing leaked documents in urging House to take action against FBI's ongoing use of BIE label under different term).

104 J. Oliver Conroy, They Hate the US Government, and They're Multiplying: The Terrifying Rise of 'Sovereign Citizens,' THE GuARdian (May 15, 2017, 6:00 AM), https://www.theguardian.com/world/2017/may/15/sovereign-citizens-rightwing-terrorismhate-us-government [https://perma.cc/3MH2-97WQ].

105 OfFice of Intelligence \& Analysis, U.S. DeP'T of Homeland SeC., IA-0257-09, (U//FOUO) Rightwing Extremism: Current Economic and Political Climate Fueling RESURGENCE IN RADiCALIZATION AND RECRUITMENT 1, 3, 8 (2009), https://fas.org/irp /eprint/rightwing.pdf [https://perma.cc/Y4BT-9TK4].

106 Conroy, supra note 104.

107 Will Parrish \& Sam Levin, 'Treating Protest as Terrorism': US Plans Crackdown on Keystone XL Activists, The GuARDIAN (Sept. 20, 2018, 4:00 AM), https://www.the guardian.com/environment/2018/sep/20/keystone-pipeline-protest-activism-crackdownstanding-rock [https://perma.cc/BDJ5-5G97] (referencing training on mass-arrest protocol, riot-control formations, and crowd-control procedures); see also Sam Levin, Revealed: FBI Terrorism Taskforce Investigating Standing Rock Activists, THE GUARDIAN (Feb. 10, 2017, 6:00 AM), https://www.theguardian.com/us-news/2017/feb/10/standing-rock-fbiinvestigation-dakota-access [https://perma.cc/Z7J6-LWXN] (detailing similar techniques used against Standing Rock activists). 
DAPL indigenous water protectors to "environmental rights extremists." 108 As a matter of fact, an FBI antiterrorism task force worked with police to investigate opponents of the DAPL. ${ }^{109}$ Notably, in 2004 and 2005, the FBI considered environmental extremists the number one "domestic terrorism threat" despite the fact that there were no deaths associated with environmentalist actors. ${ }^{110}$ Just like the "black extremist" label, that of "environmental extremist" justifies government surveillance, government interference, and ultimately government violence to suppress protest activity of indigenous activists. ${ }^{111}$ Within the last decade, the FBI has engaged in persistent investigation of environmentalists, just as it has of racial justice activists. ${ }^{112}$ Either coincidentally or by design, this results in the targeting of indigenous activists whose interests intersect with environmental justice. During this time of intense FBI focus on black and environmental activists, the FBI has dropped the category of white supremacist violence as a basis for investigation, making it increasingly difficult to assess the threat of white supremacy and the extent of government efforts to investigate it. ${ }^{113}$

Sadly, like law enforcement, white civilians have also historically viewed activists of color negatively - and still currently do. In the ' 60 s, whites were likely to view civil rights protests as violent and harmful, while African Americans saw them as peaceful and productive. ${ }^{114}$ In 1966, 85\% of whites polled thought that demonstrations by African Americans hurt the movement for civil rights, while a 1969 survey found that $70 \%$ of Blacks believed the

108 See Office of Intelligence \& Analysis, U.S. Dep't of Homeland Sec., Field ANAlysis RePort: (U//FOUO) TTPS USED In RECENT US PiPELINE ATtACKS By SuSPeCted Environmental Rights Extremists 2 (2017); see also Alleen Brown, The Green Scare: How a Movement That Never Killed Anyone Became the FBI's No. 1 Domestic Terrorism Threat, ThE INTERCEPT (Mar. 23, 2019, 8:32 AM), https://theintercept.com/2019/03/23 /ecoterrorism-fbi-animal-rights/ [https://perma.cc/3YAH-VA5W] (detailing Homeland Security's shift to focusing on environmental rights activists as potential terrorist threats).

109 Levin, supra note 107 (reciting accounts of three individuals approached by FBI due to their connection with Standing Rock water protector movement).

110 Irby, supra note 99.

111 See id. (finding that such surveillance could lead to asset seizure without a hearing); see also Parrish \& Levin, supra note 107 (noting Keystone Pipeline activists' preparation for police violence during peaceful protest).

112 GibBons, supra note 95, at 6-12 (analyzing FBI activity in connection with racial justice protests and environmental protests).

113 Sandra Fulton, Opinion, FBI Must Come Clean on Targeting Racial-Justice Activists Before Sweeping Surveillance Powers Are Renewed, The Hill (Sept. 17, 2019, 6:30 PM), https://thehill.com/blogs/congress-blog/civil-rights/461822-fbi-must-come-clean-ontargeting-racial-justice-activists [https://perma.cc/RN34-JSRE] ("[T] he bureau has dropped white-supremacist violence as a category at a time when hate crimes targeting communities of color are on the rise.").

114 Mora A. Reinka \& Colin Wayne Leach, Race and Reaction: Divergent Views of Police Violence and Protest Against, 73 J. Soc. Issues 768, 774 (2017). 
demonstrations helped. ${ }^{115}$ Despite the passage of time and at least theoretical progress in racial relations, views on protests still differ by racial lines. Statistically, whites' views of protests vary based on the purported race of the protesters. Thus, $67 \%$ of whites see protests as useful in achieving social change, unless protesters are characterized as black, in which case the number drops to $45 \% .{ }^{116}$ Whites are also more likely to justify violence perpetrated by police during protests. Only $33 \%$ of whites believed police violence in the Ferguson protests was unjustified, while $65 \%$ of African Americans found it unjustified. ${ }^{117}$ Yet whites are less forgiving of violence by protesters in predominantly black protests. For example, $68 \%$ of whites thought activists who acted aggressively during protests of the police killing of Freddie Gray were "opportunistic criminals," while $55 \%$ of African Americans saw violent acts by protesters as caused by "legitimate outrage." 118

\section{PRotest CASES AS A SOURCE OF INQUiRy For CRITICAL RACE THEORISTS}

Knowing that protests are no different than regular street encounters in that people of color are more likely to experience police violence, the doctrinal impediments that aggregate to facilitate police abuse of protesters should concern critical race theorists. The Fourth Amendment sets particular impediments in the emblematic protest scenario, where police use force to disperse instead of detain activists. As a threshold matter, courts may find that the Fourth Amendment does not apply where police were using force not to arrest but to disperse activists. This ends the possibility of any Fourth Amendment redress. ${ }^{119}$ Even if a court finds that the Fourth Amendment does apply, the court may utilize a collective lens in mass protests and evaluate the constitutionality of an officer's conduct in light of the conduct of the crowd instead of the conduct of the individual plaintiff. This approach is contrary to traditional Fourth Amendment analysis and dilutes any protection the Fourth

115 Elahe Izadi, Black Lives Matter and America's Long History of Resisting Civil Rights Protesters, WAsh. Post: The FIX (Apr. 19, 2016, 7:00 AM), https://www.washington post.com/news/the-fix/wp/2016/04/19/black-lives-matters-and-americas-long-history-ofresisting-civil-rights-protesters/.

116 Reinka \& Leach, supra note 114, at 774.

117 Id. (discussing 2014 Pew poll that highlighted this difference in opinion).

118 Id. (citation omitted).

119 When the Court finds that the Fourth Amendment does not apply, it often finds that there was no due process violation either because that requires the plaintiff to meet the high burden of showing that the police conduct "shocks the conscience." See Chavez v. Martinez, 538 U.S. 760, 775 (2003) (describing unconstitutional police conduct under due process clause as "egregious" or "conscience shocking"); County of Sacramento v. Lewis ex rel. Estate of Lewis, 523 U.S. 833, 846 (1998) ("To this end, for half a century now we have spoken of the cognizable level of executive abuse of power as that which shocks the conscience."). 
Amendment provides. Returning to the pipeline protests, the district court's first ruling in Dundon v. Kirchmeier - denying the plaintiffs' motion to enjoin police from using less-than-lethal weapons and water hoses to confront water protectors $^{120}$ - demonstrates how the Fourth Amendment can fail activists of color in dispersal cases.

\section{A. Due to Troubling Developments in Court Doctrine, the Fourth Amendment Arguably Does Not Apply in the Emblematic Protest Scenario Where Police Use Force to Disperse Protesters}

In his Fourth Amendment analysis of the excessive-force claim in Dundon, Chief Judge Daniel Hovland reasoned that the Fourth Amendment may not even apply because activists were never arrested or affirmatively detained by police. ${ }^{121}$ This argument was advanced by the defendants in their Motion to Dismiss, where they relied on Fourth Amendment precedent to argue that because the police did not intend to detain the water protectors, they were never seized and thus the Fourth Amendment could not even apply. ${ }^{122}$ This is because the Supreme Court in California v. Hodari D. ${ }^{123}$ concluded that a person is seized either when being physically touched by police or when submitting to state authority. ${ }^{124}$

The Supreme Court greatly limited Fourth Amendment protection when it defined a seizure narrowly in Hodari D. Hodari D. argued that the Fourth Amendment protected him when he saw police chasing him and knew that he was not free to leave. ${ }^{125}$ However, the majority — via Justice Scalia — engaged in a literal analysis stating that " $[\mathrm{t}]$ the word 'seizure' readily bears the meaning of a laying on of hands or application of physical force." 126 Post-Hodari D., the Fourth Amendment does not apply unless a police officer physically touches the individual or the individual submits to a government show of authority. ${ }^{127}$ In his

120 Dundon v. Kirchmeier, No. 1:16-cv-00406, 2017 WL 5894552, at*20 (D.N.D. Feb. 7, 2017), aff'd mem., 701 F. App'x 538 (8th Cir.) (per curiam) (“[T] he Court finds no reasonable juror could conclude the level of non-lethal force used by law enforcement officers during the chaos on November 20, 2016, at the Backwater Bridge was objectively unreasonable.”).

121 Id.

122 Memorandum of Law in Support of Defendants Kyle Kirchmeier et al. Motion to Dismiss at 39, Dundon v. Kirchmeier, No. 1:16-cv-00406 (D.N.D. Feb. 6, 2017), 2017 WL 3071655 [hereinafter Dundon Defendants' Motion to Dismiss] ("The Supreme Court subsequently clarified the termination or restraint upon a person's freedom of movement must be through 'means intentionally applied' to constitute a 'seizure'- an unintentional act cannot result in a seizure." (citing Brendlin v. California, 551 U.S. 249, 254 (2007))).

123499 U.S. 621 (1991).

${ }^{124}$ Id. at 627-28; see also Renée Paradis, Note, Carpe Demonstratores: Towards a BrightLine Rule Governing Seizure in Excessive Force Claims Brought by Demonstrators, 103 Colum. L. Rev. 316, 318 (2003).

125 Hodari D., 499 U.S. at 627-28.

126 Id. at 626.

127 Id. 
dissent, Justice Stevens — joined by Justice Thurgood Marshall—criticized this narrowing as inconsistent with the goal of deterring police misconduct because it determined whether the Fourth Amendment applied to the interaction based on how the civilian responded, not on how the police behaved. ${ }^{128}$ Unless the person gives into police force, there is no literal seizure. It does not matter if the show of force is unwarranted, violent, or unsupported by probable cause. The dissent focused on how this limiting of the seizure - and, therefore, of the application of the Fourth Amendment-ignores the "coercive and intimidating" effects of police conduct. ${ }^{129}$ Justice Stevens worried that "[i]t [was] too early to know the consequences of [Hodari D.'s] holding. If carried to its logical conclusion, it will encourage unlawful displays of force that will frighten countless innocent citizens into surrendering whatever privacy rights they may still have." 130

Fast forwarding from Hodari D. to Dundon, Chief Judge Hovland reasoned that since there was no physical laying of hands (and no arrests), the water protectors were not seized and the Fourth Amendment did not apply at all to any of the police conduct. ${ }^{131}$ According to the judge, the water protectors could have just complied with police orders to disperse. ${ }^{132}$ This conclusion ignored the plaintiffs" reports that some were "locked in by [tear] gas, and also blinded and gagging," decked to the ground by the force of the water, and that about two hundred were physically injured. ${ }^{133}$ Moreover, as mentioned in prior discussion, the Graham Court defined a seizure as some sort of restraint on personal liberty pursuant to Terry v. Ohio. ${ }^{134}$ Further and consistent with the Hodari D. dissent, doing away with Fourth Amendment concerns simply by concluding that there was no seizure completely discounts how the police behaved in the confrontation. This limiting of Fourth Amendment protection fails to deter police violence and militaristic responses to activists. In Dundon, this limitation allowed the district judge's easy denial of the injunction, thereby permitting law enforcement to continue this manner of assault on water protectors, which included blasting them for hours with water cannons, tear gas, concussion and other grenades, rubber bullets, and bean bag projectiles. ${ }^{135}$ A more protective Fourth Amendment analysis would not necessitate a literal seizure but would

${ }^{128}$ Id. at 646 (Stevens, J., dissenting) ("The deterrent purposes of the exclusionary rule focus on the conduct of law enforcement officers and on discouraging improper behavior on their part, and not on the reaction of the citizen to the show of force." (footnote omitted)).

129 Id. at 645-46.

$130 \mathrm{Id}$. at 646-47.

131 Dundon v. Kirchmeier, No. 1:16-cv-00406, 2017 WL 5894552, at*18 (D.N.D. Feb. 7, 2017), aff'd mem., 701 F. App'x 538 (8th Cir.) (per curiam).

132 Id.

133 Id. at *4-5 (citations omitted); Dundon Amended Complaint, supra note 1, at 3.

134 See supra note 46 and accompanying text.

135 See Dundon, 2017 WL 5894552, at *3 (listing various responses of law enforcement to protests). 
instead exalt the liberty rationale of the Fourth Amendment. As the dissent in Hodari D. stated, Terry expanded the ambit of Fourth Amendment seizures to interactions that did not amount to arrests - to "restraint[s] of an individual's personal liberty 'in some way." ${ }^{136}$ In Dundon, police intruded not only on the water protectors' right to be left alone but importantly also on their right to protest, object to, and dissent from the construction of DAPL. Thus, the court should have exalted the water protectors' liberty interests instead of discounting them because they had not been arrested or told that they could not leave. ${ }^{137}$ The proper balance may be that where the liberty interest involves First Amendment conduct, the court must more scrupulously examine the government's intrusion. ${ }^{138}$ In other words, where law enforcement seeks to police or regulate expression - not criminal conduct - the Graham reasonableness test must be adapted to protect the expressive conduct.

Other courts are divided regarding how the Fourth Amendment applies to dispersal cases. ${ }^{139}$ A court could just assume that the police conduct implicates the Fourth Amendment. This was the district judge's approach in Lamb v. City of Decatur, ${ }^{140}$ where police used pepper spray against a group of protesters. ${ }^{141}$ However, it is unclear from the opinion whether the defendants made the argument that there was no seizure. In Marbet $v$. City of Portland, ${ }^{142}$ the City and the police officers contended that the Fourth Amendment did not apply to their use of pepper spray and rubber bullets or to their act of physically moving activists who were protesting the Bush presidency. ${ }^{143}$ The factual narrative suggests that the plaintiffs were not arrested. ${ }^{144}$ The court disagreed with the defendants and had no problem finding that a seizure occurs when police use "physical force to restrain movement, even when it is ultimately unsuccessful." 145 The Marbet judge found that the attempt to control the activists' movement was determinative of the case's outcome. ${ }^{146}$

\footnotetext{
136 California v. Hodari D., 499 U.S. 621, 637 (1991) (Stevens, J., dissenting) (quoting Terry v. Ohio, 392 U.S. 1, 19 n.16 (1968)).

137 See Dundon, 2017 WL 5894552, at *18 ("Plaintiffs have neither alleged they were arrested or detained by law enforcement officials ... nor alleged they were informed by law enforcement officers they were not free to leave and walk away.").

138 See Zurcher v. Stanford Daily, 436 U.S. 547, 564 (1978) ("Where the materials sought to be seized may be protected by the First Amendment, the requirements of the Fourth Amendment must be applied with 'scrupulous exactitude."' (quoting Stanford v. Texas, 379 U.S. 476, 485 (1965))).

139 See Paradis, supra note 124, at 334-41 (describing uncertainties that exist in Fourth Amendment case law regarding public protests and dispersal).

140947 F. Supp. 1261 (C.D. Ill. 1996).

${ }^{141} I d$. at 1263.

142 No. 1:02-cv-01448, 2003 WL 23540258 (D. Or. Sept. 8, 2003).

143 Id. at * 10 .

144 Id. at *1.

145 Id. at $* 10$.

${ }^{146} \mathrm{Id}$.
} 
This focus on the police conduct is useful when at least part of the objective is to deter police violence. In Quraishi v. St. Charles County, ${ }^{147}$ the district court again focused on the actions of law enforcement, ruling that journalists in the streets of Ferguson reporting on the police shooting of Michael Brown were seized when the police sprayed them with tear gas. ${ }^{148}$ The judge stated that "[f]iring tear gas, pepper spray, or other chemical agents at someone can constitute a seizure under the Fourth Amendment." 149 In direct contrast, in the case of Ellsworth v. City of Lansing, ${ }^{150}$ the judge did not engage in any Fourth Amendment analysis when police teargassed protesters. In support of this conclusion, the judge cited County of Sacramento v. Lewis ${ }^{151}$ and stated parenthetically, without any further discussion, that "where no seizure occurs, [a] claim of excessive force is analyzed under the substantive due process standard, rather than [the] Fourth Amendment reasonableness standard."152 Likewise, in a lawsuit surrounding a protest of the police involved in the killing of Eric Garner, the judge concluded that law enforcement's use of long-range acoustic devices ("LRADs") against activists did not implicate the Fourth Amendment. ${ }^{153}$ The judge stated that "[a]n officer's request to leave an area, even with use of force, is not a seizure unless 'accompanied by the use of sufficient force intentionally to restrain a person and gain control of his movements."'154

Also, another district court stated that, when assessing whether to evaluate the police conduct pursuant to the Fourth Amendment, a court may differentiate between protesters depending on where each was situated and make judgments regarding who was able to escape the scene and who was essentially captured

147 No. 4:16-cv-01320, 2019 WL 2423321 (E.D. Mo. June 10, 2019), appeal docketed, No. 19-2462 (8th Cir. July 12, 2019).

148 Id. at $* 8-9$.

149 Id. at *9 (citation omitted).

15034 F. Supp. 2d 571 (W.D. Mich. 1998), aff'd, 205 F.3d 1340 (2000).

151523 U.S. 833, 846-48 (1986).

152 Ellsworth, 34 F. Supp. 2d at 580-81 (concluding that police conduct did not shock conscience and therefore did not violate due process).

153 Edrei v. City of New York, 254 F. Supp. 3d 565, 574 (S.D.N.Y. 2017), aff'd sub nom. Edrei v. Maguire, 892 F.3d 525 (2d Cir. 2018).

${ }^{154}$ Id. (quoting Salmon v. Blesser, 802 F.3d 249, 255 (2d Cir. 2015)). Interestingly, however, the Second Circuit subsequently held that even though the Fourth Amendment did not apply, the plaintiffs had asserted a sufficient substantive due process claim for excessive force. Maguire, 892 F.3d at 529 ("[W]e hold that purposefully using a LRAD in a manner capable of causing serious injury to move non-violent protesters to the sidewalks violates the Fourteenth Amendment under clearly established law."). The Second Circuit based this conclusion on what the court perceived as a new articulation of due process excessive-force claims that essentially uses the same tests for excessive force under the Fourth and Fourteenth Amendments. See id. at 534-38. 
by chemical agents. ${ }^{155}$ This type of plaintiff-by-plaintiff analysis is not helpful in terms of regulating police conduct or in terms of decreasing the likelihood of the aggressive use of chemical agents by law enforcement when responding to protesters. Again, this is because such analysis defines whether the Fourth Amendment offers protection based on how the police aggression affected the victims and not based on whether the conduct was wrongful and excessive in the first place.

Thus, for some courts, the Supreme Court precedent defining seizure has arguably removed Fourth Amendment protections from the typical protest scenario, in which law enforcement use militaristic force and military grade weapons to disperse protesters. ${ }^{156}$ Section 1983, by its own language, is a tool to "redress" violations of individual's constitutional rights by any person acting on behalf of the government. ${ }^{157}$ A literal interpretation of the Fourth Amendment seizure language in the context of dispersal cases therefore violates the remedial purposes of the Act. The vehicle that the Court has determined will vindicate victims' rights is arguably not available in a swath of protest cases. ${ }^{158}$

\section{B. Protesters as Unit}

Even when a court finds that the Fourth Amendment applies to the police conduct, the court may use a distorted lens to assess civilian behavior that unduly amplifies the threat protesters pose to officer and public safety. Because the Fourth Amendment excessive-force analysis involves balancing to assess "reasonableness," a miscalculation of protesters' conduct leads to a miscalculation of the degree of police force that is reasonable.

The question in excessive-force cases is theoretically a balancing between the conduct of the target and the response of police. The court engages in this

155 Buck v. City of Albuquerque, No. 1:04-cv-01000, 2007 WL 9734037, at *30-32 (D.N.M. Apr. 11, 2007) (stating that seizure "depend[s] on a Plaintiff's location" and whether "a reasonable person could have concluded that he or she was not free to leave the area or otherwise terminate the encounter," while considering seizure by chemical agents and physical contact separately).

156 See Pita Loor, supra note 62, at 26-27; see also Dundon v. Kirchmeier, No. 1:16-cv00406, 2017 WL 5894552, at*18 (D.N.D. Feb. 7, 2017), aff'd mem., 701 F. App'x 538 (8th Cir.) (per curiam); Wood, supra note 13, at 41-42.

157 See 42 U.S.C. $\S 1983$ (2018).

158 The Dundon defendants also reasoned that any Fourteenth Amendment due process claim would be more challenging for plaintiffs because the requirement that conduct "shock the conscience" is a more burdensome standard than an "objective reasonableness" analysis. Dundon Defendants' Motion to Dismiss, supra note 122, at 51. Although the language of both the due process test and the Fourth Amendment test would suggest that this is a reasonable inference, there might not be an actual difference in terms of plaintiffs' likelihood of success because both constitutional provisions require a showing of bad motive. See Brown, supra note 56, at 1274 ("Whether analyzing the use of force under the fourth amendment or the fourteenth, most courts find a constitutional violation only when the defendants have acted unreasonably and with improper motivation."). 
balancing by evaluating: (1) the severity of the crime, (2) whether there is an immediate threat, and (3) whether the target is resisting arrest or trying to flee. ${ }^{159}$ As discussed in Part I, Graham's permissive language about the "split-second decisions" police must make provides too much deference to aggression by law enforcement. ${ }^{160}$ This deference sets a low bar for police aggression because judges attribute mistakes in police judgments to "tense, uncertain, and rapidly evolving" circumstances. ${ }^{161}$ In the protest scenario, courts further compound the assessment of the threat that police face by weighing the actions of the crowd of protesters in conjunction with the actions of the individual plaintiff-protesters. This is contrary to traditional Fourth Amendment analysis, which inquires whether the government intrusion is reasonable in light of the individual's actions - not the actions of those in proximity or even of his associates. ${ }^{162}$ Just like a police officer should not be able to arrest someone in proximity to a lawbreaker, the officer should not be able to use force against someone in proximity to a lawbreaker. After all, police are permitted to use force as justified by their official duties - not because they have some natural right to use force against the general public. If the court considers the actions of the crowd as a unit versus the actions of an individual plaintiff-protester, then the threat calculus is off balance and the court will justify what would otherwise be unconstitutional police violence.

The Dundon defendants advocated for this mode of analysis before the district court. Even though there was no allegation that the Dundon plaintiffs were anything other than peaceful, the defendants argued that police force was reasonable because the plaintiffs were part of a unit that was behaving unlawfully. In their motion to dismiss, the defendants stated that the plaintiffs "were intermingled [with others who] were engaged in removing and attempting to remove government property from Law Enforcement's barricade prior to force allegedly being applied to them. The only reasonable inference is [that] the unlawful conduct of the protesters ... motivated Law Enforcement's alleged use

\footnotetext{
159 See Graham v. Connor, 490 U.S. 386, 396 (1989) ("Because "[t]he test of reasonableness under the Fourth Amendment is not capable of precise definition or mechanical application,' ... its proper application requires careful attention to the facts and circumstances of each particular case, including the severity of the crime at issue, whether the suspect poses an immediate threat to the safety of the officers or others, and whether he is actively resisting arrest or attempting to evade arrest by flight." (first alteration in original) (citation omitted) (quoting Bell v. Wolfish, 441 U. S. 520, 559 (1979))).

160 See supra notes 48-49 and accompanying text (arguing that such a permissive standard effectively immunizes large swath of aggressive police conduct).

161 Graham, 490 U.S. at 397.

162 See Ybarra v. Illinois, 444 U.S. 85, 91 (1979) (“'[A] person's mere propinquity to others independently suspected of criminal activity does not, without more, give rise to probable cause to search that person. Where the standard is probable cause, a search or seizure of a person must be supported by probable cause particularized with respect to that person." (emphasis added) (citation omitted)).
} 
of force." ${ }^{163}$ The defendants further cited Carr v. District of Columbia ${ }^{164}$ for the proposition that a "requirement that the officers verify that each and every member of a crowd engaged in a specific riotous act would be practically impossible in any situation involving a large riot." 165 Thus, the defendants argued that the use of force was reasonable to control the crowd or unit rather than to control the plaintiffs specifically. ${ }^{166}$

The Dundon defendants' reference to Carr is significant because the concept of unit probable cause was initially adopted by the court in that case. ${ }^{167}$ In that case, the D.C. District Court had ruled that the plaintiff protesters' arrests violated the Fourth Amendment because the police could not establish that each of the people they arrested was engaged in the crime of rioting. ${ }^{168}$ The D.C. Circuit reversed, holding that the police need only show a "reasonable belief that the entire crowd is acting as a unit and therefore all members of the crowd violated the law." 169 The D.C. Circuit accepted the risk that an innocent protester could be swept up in the arrest highlighting that the question was one of probable cause, not final conviction. ${ }^{170}$ However, this language minimizes how far of a departure this type of group analysis is from the probable cause requirement of individualized suspicion. In the protest scenario, it also ignores how this group analysis harms activists' right to express dissent - thus undervaluing protest activity. This concept of unit probable cause espouses guilt by association and thus dilutes the Fourth Amendment beyond recognition. The rights of activists who participate in mass protests are in particular danger in jurisdictions that adopt this group analysis.

Returning to Dundon, the district judge referenced the "chaotic scenario"171 and the "sizeable minority of protesters ... [whom he] categorized as a group of unlawful and violent agitators" when he denied the injunction. ${ }^{172}$ The judge ruled that if the Fourth Amendment applied, no reasonable juror could find that

163 Dundon Defendants' Motion to Dismiss, supra note 122, at 2.

164587 F.3d 401, 408 (D.C. Cir. 2009).

165 Dundon Defendants' Motion to Dismiss, supra note 122, at 27 (quoting Bernini v. City of St. Paul, 665 F.3d 997, 1003 (8th Cir. 2012)).

${ }^{166} I d$. at 28-32; id. at 31 ("Regardless, Bernini establishes the use of non-lethal munitions upon an unruly crowd, which officers reasonably believe is acting as a unit, to prevent the crowds unlawful access to property and to restore order, is objectively reasonable as a matter of law.").

167 Id. at 27-28 (citing Bernini, 665 F.3d at 1003).

168 Carr, 587 F.3d at 405-06.

169 Id. at 408.

${ }^{170} I d$. ("Probable cause only requires a reasonable belief of guilt, not a certitude." (citing Brinegar v. United States, 338 U.S. 160, 175 (1949))).

171 Dundon v. Kirchmeier, No. 1:16-cv-00406, 2017 WL 5894552, at*19 (D.N.D. Feb. 7, 2017), aff'd mem., 701 F. App'x 538 (8th Cir.) (per curiam).

172 Id. at *8. 
the force was unreasonable. ${ }^{173}$ The judge focused on the overall scene and volatility of the crowd - instead of the specific acts of the plaintiffs - suggesting that he was persuaded by the defendants' reference to Carr and to a group/unit analysis.

Since Carr was decided in 2009, various jurisdictions have progressively embraced this Fourth Amendment unit analysis in protest cases. The Dundon defendants were well situated because the Eighth Circuit had already adopted group probable cause in Bernini v. City of St. Paul. ${ }^{174}$ In Bernini, the court found that police did not violate the Fourth Amendment when arresting a large group of protesters at the Republican National Convention, even though the officers were unable to articulate probable cause for each person arrested. Citing Carr, the court determined that

[w] hat is reasonable in the context of a potential large-scale urban riot may be different from what is reasonable in the relative calm of a tavern with a dozen patrons.... [T] he Fourth Amendment "is satisfied if the officers have grounds to believe all arrested persons were a part of the unit observed violating the law." 175

In another Eighth Circuit case, the court applied group probable cause to Ferguson protesters. ${ }^{176}$ The court concluded that the plaintiffs' arrests for failure to disperse were reasonable because they "chose not to disassociate" themselves from the group throwing debris at police and instead continued to walk while "in the vicinity of a violent crowd" toward the line of police shooting rubber bullets at them. ${ }^{177}$ Thus, the proximity of the plaintiffs to an unlawful crowd justified the police's violent conduct.

As an example of the growing acceptance of this looser, group probable cause standard for protests, courts within the Second Circuit — courts that previously rejected group probable cause - are increasingly embracing it for mass protests. In a pre-Carr decision, the Second Circuit ruled in Papineau v. Parmley ${ }^{178}$ that police violated the Fourth Amendment when they beat and violently arrested indigenous protesters indiscriminately. ${ }^{179}$ Because the police admitted that they could not identify whether any of the plaintiffs were actually blocking the roadway — which was necessary for a disorderly conduct arrest — the court ruled

\footnotetext{
173 Id. at $* 19$.

174665 F.3d 997, 1001 (8th Cir. 2012) (emphasis added) (considering mass arrests of approximately one hundred protesters surrounding Republican National Convention).

175 Id. at 1003 (quoting Carr, 587 F.3d at 407).

176 White v. Jackson, 865 F.3d 1064, 1069 (8th Cir. 2017) (considering claims by six sets of plaintiffs arrested during protest).

177 Id. at $1075-79$.

178465 F.3d 46 (2d Cir. 2006).

$179 I d$. at 53 (describing violent police action including "beating [protesters] with their riot batons, dragging them by their hair and kicking them," choking a praying man, manhandling both an eleven-year-old girl and an elderly medicine woman, and "even toss[ing] an infant in a double leg cast from his stroller").
} 
that the police could not have reasonably believed that the mass arrest was justified because a few protesters had violated the law. ${ }^{180}$ The court further articulated how a rule that would permit the unlawful actions of some to be attributed to the whole group would affect the First Amendment in that "we see little that would prevent the police from ending a demonstration without notice for the slightest transgression by a single protester." 181

Post-Carr, in Dinler v. City of New York, ${ }^{182}$ the defendants cited group probable cause pursuant to Carr, arguing that police could arrest the entire group "where it reasonably appears to the police that a large group is engaging in unlawful conduct." 183 A judge in New York's Southern District, citing the principle of individualized probable cause espoused in Ybarra v. Illinois, ${ }^{184}$ rejected the defendants' arguments that they possessed probable cause to arrest Republican National Convention protesters for obstruction of traffic and defying a police order to disperse. ${ }^{185}$ However, the judge did not specifically reject Carr's reasoning, stating that Carr did not really promulgate a new probable cause standard but instead "stand[s] for the unremarkable proposition that, where a group of individuals is acting in concert such that a reasonable officer could conclude that every member of the group violated the law, that officer would be justified in arresting every member of the group." ${ }^{186}$ Calling the Carr proposition "unremarkable" in the realm of probable cause is a mischaracterization because it deviates from individualized suspicion.

The same year and in the same district, in Garcia v. Bloomberg, ${ }^{187}$ another judge rejected the defendants' arguments to treat seven hundred Occupy Wall Street marchers as a group because even if not all protesters heard the police warnings to avoid the street, some did, and law enforcement could then arrest all of them for disorderly conduct pursuant to Carr. ${ }^{188}$ The district judge distinguished Carr by differentiating between violent rioters and peaceful protesters. ${ }^{189}$ However, the Second Circuit sitting en banc reversed without mentioning Carr, instead highlighting the "confused and boisterous situation confronting the officers" and noting that some protesters were able to hear the

180 Id. at 59.

181 Id. at 57.

182 No. 1:04-cv-07921, 2012 WL 4513352 (S.D.N.Y. Sept. 30, 2012).

183 Id. at *4 (quoting Defendant's Memorandum of Law in Support of Their Motion for Summary Judgment to Dismiss the False Arrest Claims of Plaintiffs Arrested on East 16th Street at 9, Dinler, 2012 WL 4513352 (No. 1:04-cv-07921)).

184444 U.S. 85 (1979).

185 Dinler, 2012 WL 4513352, at *5.

${ }^{186} I d$.

187865 F. Supp. 2 d 478 (S.D.N.Y. 2012), aff'd sub nom. Garcia v. Does, 764 F.3d 170 (2d Cir. 2013), rev'd en banc, 779 F.3d 84 (2d Cir. 2015).

${ }^{188} \mathrm{Id}$. at 489-90 (finding that protesters were nonviolent and therefore did not receive fair warning prior to their arrest).

189 Id. 
police warning yet made no attempts to disperse. ${ }^{190}$ This was sufficient for the Second Circuit to conclude that there was probable cause to arrest all protesters for disorderly conduct. ${ }^{191}$ While the Second Circuit did not allude to group probable cause in Garcia, the ruling that failure of some protesters to heed police orders was sufficient to result in the arrest of seven hundred individuals demonstrates that the court allowed the actions of some activists to be attributed to the entire group.

This looser probable cause standard means that police can easily justify the indiscriminate use of violent tactics and less-than-lethal weapons when they assert that violent protesters were in the vicinity. This standard substantially deviates from and is inconsistent with traditional individualized determinations of suspicion.

\section{CONCLUSION}

Police officers' targeting of protesters of color is unlikely to end considering that it dates back to the beginning of the American republic. Whether quelling slave rebellions, ${ }^{192}$ cracking down on a Mexican American rally against Chicano casualties in the Vietnam War, ${ }^{193}$ or suppressing civil rights marchers in Selma, ${ }^{194}$ government authorities have consistently responded brutally to dissent from people of color. When nonwhite activists challenge the status quo, law enforcement reacts with military-grade force to quash protests. Protesters of color have few allies because the white majority — which benefits from the status quo - sees these protest movements as generally corrosive to society and to progress. ${ }^{195}$ The courts are not allies either. Instead, harmful Fourth Amendment doctrines coalesce to facilitate police abuse of activists of color.

This Essay demonstrates how the Fourth Amendment fails to provide protection in the emblematic protest scenario, in which law enforcement employs brutal and often militaristic force to disperse protesters. Simultaneously, the Fourth Amendment also fails its own roots, deviating from the principle of individualized suspicion in favor of group suspicion. This

190 Garcia v. Does, 779 F.3d 84, 93-94 (2d Cir. 2015) (en banc).

191 Id. at 94-96.

192 Stephen L. Carter, Opinion, Policing and Oppression Have a Long History, BLOOMBERG OPINION (Oct. 29, 2015, 6:19 PM), https://www.bloomberg.com/opinion/articles /2015-10-29/policing-and-oppression-have-a-long-history [https://perma.cc/H4XN-74JB]; Chelsea Hansen, Slave Patrols: An Early Form of American Policing, NAT'L L. ENFORCEMENT Museum: ON THE BEAT (July 10, 2019), https://lawenforcementmuseum.org /2019/07/10/slave-patrols-an-early-form-of-american-policing/ [https://perma.cc/89CX86DC].

193 Mario T. García, An Important Day in U.S. History: The Chicano Moratorium, NAT'L CATH. ReP.: NCR TODAY (Aug. 27, 2015), https://www.ncronline.org/blogs/ncrtoday/important-day-us-history-chicano-moratorium [https://perma.cc/3FKH-PELU].

194 March 7, 1965: Civil Rights Marchers Attacked in Selma, N.Y. Times: LEARNING NeTwORK (Mar. 7, 2012, 4:07 AM), https://learning.blogs.nytimes.com/2012/03/07/march7-1965-civil-rights-marchers-attacked-in-selma/.

195 See Izadi, supra note 115. 
analysis suggests that courts should recalibrate their treatment of policeexcessive-force claims in mass protest cases in order to reign in law enforcement abuse and to be more protective of activists' rights to dissent. An alternative analysis should elevate protest rights and apply a more rigorous Fourth Amendment review when the police seek to control expressive conduct. 